\title{
ZABURZENIA MOWY A TRUDNOŚCI W CZYTANIU I PISANIU
}

\section{SPEECH DISORDERS AND DIFFICULTIES WITH READING AND WRITING}

\author{
Beata Wołosiuk $\mathbf{k}^{1(\mathrm{~A}, \mathrm{~B}, \mathrm{C}, \mathrm{D}, \mathrm{E}, \mathrm{F}, \mathrm{G})}$
}

${ }^{1}$ Państwowa Szkoła Wyższa im. Papieża Jana Pawła II w Białej Podlaskiej

\begin{abstract}
Wołosiuk, B. (2018). Zaburzenia mowy a trudności w czytaniu i pisaniu. Rozprawy Społeczne, 12(4), 56-64.
\end{abstract}
https://doi.org/10.29316/rs.2018.37

Wkład autorów:

A. Zaplanowanie badań

B. Zebranie danych

C. Dane - analiza i statystyki

D. Interpretacja danych

E. Przygotowanie artykułu

F. Wyszukiwanie i analiza

literatury

G. Zebranie funduszy
Tabele: 0

Ryciny: 6

Literatura: 26

Otrzymano: czerwiec 2018

Zaakceptowano: sierpień 2018

\begin{abstract}
Streszczenie
Wstęp. Mowa, która jest dźwiękowym porozumiewaniem się ludzi, pełni ważną rolę w życiu człowieka. Prawidłowy rozwój mowy jest bardzo ważnym elementem dojrzałości szkolnej dziecka. Zaburzenia mowy mogą być przyczyną m.in. trudności w czytaniu i pisaniu. W części teoretycznej zostanie omówiony wpływ zaburzeń mowy (głównie dyslalii) na specyficzne trudności w czytaniu i pisaniu. W związku z tym zostanie przedstawione zagadnienie dotyczące rozwoju mowy i najczęściej występujących wad mowy. Zaprezentowany również zostanie problem dotyczący specyficznych trudności w uczeniu się.

Materiał i metody. Badania dla potrzeb niniejszej publikacji realizowano we wrześniu 2018 wśród 62 uczniów klas I-III wybranych szkół podstawowych powiatu bialskiego, u których stwierdzono zaburzenia artykulacyjne. Celem badań była analiza komunikacji werbalnej dzieci w kontekście trudności w czytaniu i pisaniu. Podstawowym narzędziem wykorzystanym w badaniu była część kwestionariusza obrazkowego, skonstruowanego przez G. Demel.

Wyniki. Analiza zebranych wyników badań empirycznych pozwala stwierdzić, że wśród dzieci mających zdiagnozowane zaburzenia artykulacyjne, występują specyficzne trudności w czytaniu i pisaniu.
\end{abstract}

Wnioski. Zaburzenia artykulacyjne wpływają na trudności w czytaniu i pisaniu.

Słowa kluczowe: mowa, zaburzenia mowy, trudności w czytaniu i pisaniu

\section{Summary}

Introduction. Speech, which is the sonic communication of people, plays an important role in human life. The correct development of speech is a very important element of a child's school maturity. Speech disorders may be the cause of, among others, difficulties with reading and writing. The theoretical part will discuss the impact of speech disorders (mainly dyslalia) on specific difficulties with reading and writing. In relation to this, the issue of speech development and the most frequently occurring speech disorders will also be presented. The problem of specific difficulties with learning will also be presented.

Material and methods. Studies for the purposes of the present publication were conducted in September 2018 among 62 students in grades 1-3 of selected primary schools of in the Biała Podlaska district, in whom articulation disorders have been diagnosed. The aim of the research was to analyse the verbal communication of children in the context of difficulties with reading and writing. The basic tool used in the study was a part of the pictorial questionnaire created by G. Demel.

Results. The analysis of the collected results of empirical research allows to conclude that among children diagnosed with articulatory disorders, there are specific difficulties with reading and writing.

Conclusions. Articulatory disorders have an influence on difficulties with reading and writing.

Keywords: speech, speech disorders, difficulties with reading and writing
-Turska, 2003). Jest on związany z ogólnym rozwojem dziecka. Możemy wymienić następujące stadia rozwoju we wczesnej fazie cyklu życiowego:

- prenatalne (od poczęcia do narodzin),

- niemowlęctwo (od narodzin w prawidłowym terminie do ok. 18 miesięcy),

- wczesne dzieciństwo (od ok. 18 miesięcy do ok. 6 lat),

- późne dzieciństwo (od ok. 6 lat do ok. 13 lat) (Zimbardo, 1999). kowych i pragmatyki (umiejętnościa posługiwania się mową w różnych sytuacjach społecznych (Kielar

Adres korespondencyjny: Beata Wołosiuk, Państwowa Szkoła Wyższa im. Papieża Jana Pawła II w Białej Podlaskiej, ul. Sidorska 102, 21-500 Biała Podlaska, e-mail: beata@wolosiuk.com, tel.: 833449900

Copyright by: Państwowa Szkoła Wyższa im. Papieża Jana Pawła II w Białej Podlaskiej, Beata Wołosiuk

Czasopismo Open Access, wszystkie artykuły udostępniane są na mocy licencji Creative Commons Uznanie autorstwa-użycie niekomercyjne-na tych samych warunkach 4.0 Międzynarodowe (CC BY-NC-SA 4.0, http://creativecommons.org/licenses/by-nc-sa/4.0/). 
Podstawowym warunkiem powstania mowy jest rozwój fizjologiczny. Istotne jest, aby prawidłowo funkcjonował, ośrodkowy układ nerwowy, obwodowy aparat mowy (jama ustna, nosowa, gardło, język, narząd zębowy, podniebienie) oraz narząd słuchu.

W psychologii rozwojowej zwraca się uwagę na czynniki biologiczne (stan anatomiczno-fizjologicznego podłoża czynności mownych decydujący o dojrzałości ośrodków centralnego układu nerwowego, dynamika procesów mielinizacyjnych szlaków i struktur nerwowych biorących udział w czynnościach komunikowania się). Natomiast do czynników psychicznych kształtowania się mowy zalicza się procesy i dynamizmy aktywności dziecka (więź emocjonalna z osobą będącą wzorem mowy, potrzeba kontaktu społecznego, motywacja i gotowość do komunikowania się, potrzeba poznawcza) (Dołęga, 2003).

Przebieg okresu prenatalnego i perinatalnego determinuje rozwój mowy dziecka. Przyczyną zaburzeń centralnego układu nerwowego, a zatem zaburzeń mowy mogą być:

- choroby, które przechodzi matka w okresie ciąży, a szczególnie w pierwszym jej trymestrze,

- zaburzenia krążenia u matki,

- niedożywienie matki,

- niedobory witamin,

- szkodliwe związki chemiczne (narkotyki, alkohol, nikotyna, niektóre leki),

- urazy fizyczne i psychiczne.

Do zaburzeń rozwoju wskutek działania patogennych czynników w okresie porodu zaliczamy:

- poród przedwczesny,

- poród przedłużający się,

- urazy czaszki powstałe w czasie porodu.

Natomiast do czynników biologicznych, które wpływają na zaburzenia prawidłowego rozwoju dziecka w okresie postnatalnym można zaliczyć: choroby, które przechodzi dziecko (szczególnie przebiegające z powikłaniami), urazy czaszki połączone z wstrząsami mózgu, zatrucia lekami, zatrucia tlenkiem węgla.

P. G. Zimbardo zwraca uwagę, że „fizyczny wzrost i rozwój wielu zdolności dokonuje się według genetycznie uwarunkowanej kolejności dojrzewania, choć wczesne bodźce chemiczne i sensoryczne także odgrywają pewną rolę w dojrzewaniu. Wpływy środowiskowe mogą do pewnego stopnia modyfikować odziedziczone predyspozycje genetyczne" (Zimbardo, 1999).

Dlatego ważne jest w jakim środowisku wychowuje się dziecko. Badania prowadzone nad dziećmi wychowanymi w środowiskach instytucjonalnych np. domach dziecka, żłobkach, żłobkach tygodniowych a dziećmi wychowanymi w domach rodzinnych, pokazują istotną różnicę $\mathrm{w}$ rozwoju mowy. Dzieci wychowywane instytucjonalnie często mają opóźnienia rozwoju mowy (Dołęga, 2003). Istotny jest styl wychowania w rodzinie. W związku z tym rodzice powinni prezentować taką postawę wycho- wawczą, aby pobudzać dziecko do mówienia. Warunki i struktura rodziny wpływa na częstotliwość komunikacji werbalnej. W warunkach środowiskowych rozwój mowy zależy nie tylko od częstości mówienia, ale również od jakości i przebiegu komunikacji (Dołęga, 2003).

Sposób karmienia dziecka wpływa na rozwój aparatu artykulacyjnego. Karmienie naturalne, czyli karmienie piersią w lepszym stopniu przyczynia się do usprawnienia warg i języka niż karmienie sztuczne. Dziecko karmione piersią ma lepiej wzmocniony mięsień okrężny ust, pionizuje język, ćwiczy żuchwę, utrwala oddychanie przez nos. Nie należy dopuszczać do próchnicy, zwracać uwagę na sposób oddychania dziecka.

M.A.C. Haliliday wyróżnia trzy fazy rozwoju języka:

1. Faza I - 9-16 miesiąc życia. Dziecko posługuje się dwupoziomowym systemem, który zawiera dźwięki i znaczenia. Nie posługuje się jeszcze strukturami wyrazowymi.

2. Faza II - 16/18 a 22/24 miesiąc życia. Dziecko zaczyna posługiwać się systemem leksykalno-gramatycznym, pojawia się dialog, który daje możliwość podejmowania i przydzielania ról językowych.

3. Faza III - od 24 miesiąca życia. Dwupoziomowy system dźwiękowo - znaczeniowy zostaje zastąpiony systemem trójpoziomowym. Pojawia się funkcja ideacyjna (przedstawieniowa) (Haliliday, 1975).

Natomiast w Polsce najbardziej popularna jest periodyzacja rozwoju mowy zaproponowana przez L. Kaczmarka, który wyróżnia następujące okresy:

- okres przygotowawczy (okres prenatalny),

- okres melodii, sygnału, apelu (0 - 1 rok życia dziecka),

- okres wyrazu, sygnału jednoklasowego (1 - 2),

- okres zdania, sygnału dwuklasowego (2 - 3),

- okres swoistej mowy dziecka, swoistych form językowych (3 - 7) (Kaczmarek, 1988).

Zakłada się, że rozwój mowy pod względem artykulacyjnym powinien być zakończony pod koniec 5 roku życia. Dziecko w wieku sześciu lat, które znajduje się w końcowej fazie okresu swoistej mowy dziecięcej, powinno wymawiać wszystkie głoski i budować logiczne zdania, poprawnie używać form gramatycznych. Słownik czynny dzieci w wieku 6 lat wynosi od około 4000 do około 6000 leksemów (form wyrazowych jest wielokrotnie więcej), w tym: rzeczowników - około 50\%, czasowników - około 25\%, przymiotników i przysłówków łacznie - około 13\%, pozostałe wyrazy stanowią $10 \%$ (Zarębina, 1994). Natomiast słownik bierny jest znacznie obszerniejszy, gdyż dziecko zazwyczaj rozumie 20000 - 24000 słów. W tym wieku dziecko powinno układać zdania złożone $\mathrm{z}$ dwóch lub więcej zdań składowych połączonych „i” lub „ale”. Jednak niektóre struktury są dla niego wciąż zbyt trudne zwłaszcza rozpoczynające się od „jeżeli”. Dziecko potrafi przekazać swoje pomysły, opowiedzieć 
o swoich problemach, umie przytoczyć historyjkę składającą się z kilku części, stosuje proste gry słowne i żarty. Sześciolatek w tym okresie może zainicjować i podtrzymywać rozmowę, chociaż może jeszcze mieć problem z wyjaśnieniem niezrozumiałych części swojej wypowiedzi (Dyer, 2006).

Mowa dziecka jest przedmiotem badań wielu dyscyplin naukowych i budzi zainteresowanie przed wszystkim logopedów, językoznawców, pedagogów i psychologów.

W Polsce wymową i diagnozowaniem jej wad wśród dzieci sześcioletnich zajmowali się m.in. T. Bartkowska (1968), H. Mystkowska (1970), J. Kania (1971), E. Nitendel-Bujakowa (1975), K. Kozłowska (1981). Na podstawie badań prowadzonych w latach 60,70, 80 ubiegłego wieku, można zauważyć, że wady mowy stwierdzono u 20\%-30\% sześciolatków. Natomiast badania prowadzone w 2010 roku wykazały, że ilość osób z wadami mowy znacznie wzrosła i wynosiła 48\% (Wołosiuk, 2012).

Pomimo istniejących wielu programów, projektów, które mają na celu wspomaganie rozwoju mowy, można zaobserwować, że przybywa dzieci z zaburzeniami mowy, sześciolatki mają coraz słabiej rozwiniętą mowę. Analizując wyniki badań, można przypuszczać, iż stan ten nie jest uwarunkowany czynnikami endogennymi (np. sprawność narządów artykulacyjnych badanych dzieci nie zmieniła się znacząco na przestrzeni lat), lecz czynnikami środowiskowymi.

\section{Zagrożenia rozwoju komunikacji werbalnej}

Najważniejszym środowiskiem rozwijania myślenia i mowy dziecka jest rodzina. Późniejsze opanowanie języka jest na ogół powtarzaniem i modyfikowaniem najwcześniejszych zachowań werbalnych, utrwalonego w dzieciństwie współdziałania mowy i umysłu (Czelakowska, 2005). Dziecko, które uczy się mówić, musi słyszeć w początkowym okresie mowę w swym otoczeniu. Pod wpływem tej stymulacji wykształcają się w korze mózgu, przeważnie w lewej półkuli, obszary sterujące mową (Sadowski, 2005) .

Współcześnie człowiek żyje w świecie „wymiany informacyjnej” i komunikacji medialnej. Prawie każdy (szczególnie młody) człowiek korzysta z wielu urządzeń informacyjnych i telekomunikacyjnych, nazywanych „nowe media”, czyli telefonii komórkowej, telewizji cyfrowej, kablowej, satelitarnej, magnetowidów, internetu. Urządzenie te na pewno ułatwiają funkcjonowanie każdego człowieka i obecnie nie wyobrażamy sobie życia bez udogodnień, które zapewniają nam „nowe media”. Jednak nieumiejętne i niekontrolowane korzystanie $\mathrm{z}$ nich, szczególnie w przypadku małych dzieci może mieć przykre konsekwencje.

Z przeprowadzonych badań (Spitzer, 2013) wynika, że dzieci i młodzież spędza nawet 7,5 godziny dziennie na korzystaniu z mediów elektronicznych, czyli niejednokrotnie więcej niż wynosi ich czas spania. Bardzo często taka sytuacja może powodo- wać zaburzenia rozwoju mowy, problemy z koncentracją, problemy z czytaniem (Ennemoser, Schneider, 2007) a czasami nawet: stres, depresję, czy też gotowość do stosowania przemocy fizycznej.

Aby mowa mogła rozwinąć się w sposób pożądany, potrzebny jest pogłębiony dialog rodziców z dzieckiem. Jak słusznie zauważa Cieszyńska-Rożek: „Dialog twarzą w twarz jest prototypowym, pierwotnym i najważniejszym aktem komunikacji człowieka. Uczestnictwo w rozmowie „wymusza” wybór wyrazów z istniejącego w umyśle kodu. Ponieważ dotyczy rozgrywających się zdarzeń, ułatwia uczenie znaczeń poszczególnych słów, ale przede wszystkim zdań, a dokładnie - wyrazów w zdaniach" (Cieszyńska-Rożek, 2013).

Porozumiewanie się za pomocą SMS, czy też innych komunikatorów nie może zastępować rozmowy. Pisanie na małej klawiaturze nie jest komfortowe i często powoduje, że przesyłane wiadomości nie tylko są lakoniczne, lecz też pełne błędów gramatycznych i interpunkcyjnych. Wpływa to pośrednio na poprawność językową a w konsekwencji może powodować zaburzenia komunikacji werbalnej.

Media elektroniczne, które zapewniają nam rozrywkę, mogą wzbogacić nasze wiadomości, mogą również być źródłem zagrożenia poprawnej wymowy. Dziecko, które zbyt dużo czasu spędza przed ekranem telewizora może mieć problem z komunikacją werbalną. Niepokój może budzić fakt, że coraz młodsze dzieci korzystają z elektronicznych mediów wizualnych (telewizja, DVD, wideo), jak donosi Spiegel Online „W ostatnich latach branża telewizyjna pozyskała nową grupę odbiorców dzieci w wieku od czterech do dwudziestu czterech miesięcy. Telewizja dla niemowląt urosła do rangi gałęzi przemysłu osiągającej obroty rzędu pięciuset milionów dolarów. W latach siedemdziesiątych przeciętny wiek dziecka wchodzącego w regularny kontakt ze światem telewizji wynosił cztery lata dzisiaj zmniejszył się on do czterech miesięcy". Jak zauważa Spitzer (Spitzer, 2013), niemowlęta spędzaj przed telewizorem prawie godzinę dziennie, dwulatki ponad 1,5 godziny. Jest to sprzeczne z zaleceniami pediatrów, którzy są przeciwni korzystaniu z elektronicznych mediów wizualnych przez dzieci poniżej drugiego roku życia oraz proponują ograniczenie czasu spędzonego przed ekranem przez dzieci poniżej trzech lat (Zimmerman, 2007). Dzieci, które spędzają dużo czasu przed telewizorem (często telewizja traktowana jest jak „niania”) nie mają zbyt wiele okazji na bezpośredni kontakt słowny z rodzicami. Warto zgodzić się z Cieszyńską - Rożek, która zauważa, że dziecko przebywając w pomieszczeniu, w którym włączony jest telewizor, odbiera mowę jako dźwięk, ale jej nie słyszy jako przekaźnik znaczeń (Cieszyńska-Rożek, 2013). Neurobiolodzy podkreślają: "mózg nie może działać efektywnie przy zalewie informacyjnym (....). Normalny rozwój ludzkiego mózgu wymaga równowagi miedzy bodźcami środowiskowymi a tymi, które biorą się z kontaktów z ludźmi. Pozbawiony 
ich mózg nie działa właściwie, nie mogąc tworzyć odpowiednich połączeń neuronowych. (...) bez osobistej stymulacji interpersonalnej sieć neuronów dziecka może ulec atrofii" (Small, Vorgan, 2011).

Jeśli niemowlę, spędza czas przed telewizorem rzadziej gaworzy, wolniej przyswaja słownik bierny i czynny. Dziecko, które nie ma okazji do rozmów z rodzicami, a tylko korzysta z elektronicznych mediów wizualnych ma zahamowany rozwój ekspresji językowej, uboższe słownictwo, ma trudności z wyrażeniem swoich myśli i uczuć w sposób poprawny.

Nawet najlepszy program edukacyjny nie jest w stanie nauczyć dziecka poprawnej artykulacji i nie jest w stanie zastąpić słów wypowiadanych przez drugiego człowieka.

\section{Najczęstsze zaburzenia mowy dziecka}

Zaburzenia mowy charakteryzujemy z punktu widzenia objawów lub przyczyn. Objawowa klasyfikacja zaburzeń mowy została zaproponowana przez L. Kaczmarka, który wzorował się na opracowaniu Kussmaula. L. Kaczmarek przyjmuje, że trzy części składowe tekstu, mogą być zniekształcone, a mianowicie:

- treść

- forma językowa

- substancja (Grabias, 1994).

Styczek zaproponowała przyczynową (etiologiczną) klasyfikację, która wyróżnia następujące zaburzenia mowy:

- dysglosję

- dysartię (anartię)

- dyslalię (alalię)

- afazję

- jąkanie

- nerwice mowy (logoneurozy)

- oligofazje

- schizofazje (Styczek, 1979).

S. Grabias przedstawił jedną z najczęściej obecnie stosowaną klasyfikację, gdzie wymienia:

- zaburzenia mowy związane z niewykształconymi substancjami percepcyjnymi (głuchota, niedosłuch, alalia, dyslalia, oligofazja);

- zaburzenia mowy związane z brakiem lub niedowładem sprawności realizacyjnych (dysglosja, mowa bezkrtaniowców, giełkot, jąkanie, anartia, dyzartia);

- zaburzenia mowy, związane z rozpadem systemu komunikacyjnego (afazja, schizofazja (Grabias, 1996).

Do najczęściej występujących zaburzeń mowy możemy zaliczyć zaburzenia związane z artykulacją głosek, jąkanie oraz opóźniony rozwój mowy.

Jak zauważa H. Rodak: „Wady wymowy określane są w terminologii logopedycznej mianem dyslalii. Dyslalia jest to symptom zaburzenia rozwoju mowy dotyczący tylko jednego aspektu języka, a mianowicie artykulacyjnego. Autorzy większości prac z zakresu logopedii (M. Führing, O. Lettmayer, H. Weinert, J. Kania, G. Demelowa) rozumieją przez określenie dyslalia nieprawidłowe realizacje głosek języka ojczystego” (Rodak, 1992). G. Jastrzębowska podaje następującą definicję: „Dyslalia to zaburzenie realizacji fonemów o ściśle określonej etiologii (tj. pochodzenia obwodowego). Zaburzenia te mogą przejawiać się zniekształceniem (deformacją) dźwięków mowy, ich zastępowaniem (substytucją) bądź opuszczaniem (elizją), co powoduje, że w efekcie brzmienie odbiega od ogólnie przyjętej normy wymawianiowej" (Jastrzębowska, 2003). być:

Przyczynami zaburzeń artykulacyjnych mogą

- zmiany anatomiczne aparatu artykulacyjnego (np. nieprawidłowa budowa języka, podniebienia, wady zgryzu, anomalie zębowe, przerost adenoidu - tzw. trzeciego migdałka, skrzywienie przegrody nosa);

- zaburzenia funkcjonowania narządów artykulacyjnych (np. nieprawidłowa praca zwierającego pierścienia gardłowego, niska sprawność języka, warg, brak pionizacji języka);

- nieprawidłowa budowa i funkcjonowanie narządy słuchu;

- nieprawidłowe funkcjonowanie ośrodkowego układu nerwowego;

- psychiczne podłoże (np. brak zainteresowania mową);

- opóźniony rozwój psychomotoryczny;

- niewłaściwe warunki środowiskowe (np. nieprawidłowy wzór mowy, brak stymulacji rozwoju mowy, niewłaściwe postawy rodzicielskie) (Jastrzębowska, 2003).

Następną wadą, która dosyć często występuje, jest jąkanie, które bywa definiowane jako zakłócenie płynności, rytmu, tempa i melodii wypowiedzi na skutek braku koordynacji układu oddechowego, fonacyjnego i artykulacyjnego. Tarkowski mówi, że jąkanie jest: funkcją patologicznej niepłynności mówienia, zwykłej niepłynności mówienia, reakcji psychicznych, reakcji fizjologicznych i reakcji społecznych (Tarkowski, 2003).

Natomiast opóźnienie rozwoju mowy dziecka ujmuje się jako zespół objawów, gdy:

1. określony etap rozwoju mowy dziecka nie pojawił się w czasie powszechnie uznawanym za właściwy,

2. wydłuża się proces kształtowania i rozwoju mowy,

3. istnieją znaczące różnice pomiędzy poziomem rozwoju percepcji i ekspresji językowej,

4. opóźniony jest rozwój wszystkich aspektów mowy lub tylko niektórych z nich,

5. występują różnice pomiędzy poziomem rozwoju językowej sprawności systemowej i komunikacyjnej (Jastrzębowska, 2003).

Wpływ zaburzeń mowy na trudności w czytaniu i pisaniu

Zaburzenia artykulacyjne wpływają na trudności w czytaniu i pisaniu. Jak zauważa, B. Sawa, na podstawie przeprowadzonych badań - u 81,3\% uczniów mających wady wymowy wykazywało 
trudności w nauce czytania i pisania (Sawa, 1992). W języku polskim substancja graficzna w znacznym stopniu jest odzwierciedleniem substancji fonicznej (Skorek, 2000), zatem nieprawidłowa artykulacja wpływa na powodzenia szkolne. Dziecko z wada wymowy, zwłaszcza w klasach początkowych „pisze tak, jak mówi”, a więc błędna artykulacja danej głoski powoduje niewłaściwy zapis. Najczęściej zdarza się taka sytuacja w przypadku substytucji, czyli jeśli zastępuje daną głoskę inną. np. zamiast $r$ mówi l („rower” zastępuje słowem „lowel”).

Zdarza się, że trudności w artykulacji oraz czytaniu i pisaniu maja wspólna przyczynę np. zaburzenie koordynacji wzrokowo - ruchowej, zaburzenie percepcji wzrokowej i słuchowej, zaburzenie analizy i syntezy wzrokowej lub słuchowej. W takiej sytuacji zaburzona artykulacja nie jest bezpośrednią przyczyną trudności w nauce. Jednak współwystępując z problemami w czytaniu i pisaniu może je nasilić (Skorek, 2000).

Według A. Drath główne przyczyny trudności w czytaniu to: zaburzenie słuchu (przedłużenie czasu percepcji słuchowej) oraz zaburzenia mowy (wymowa wadliwa, brak synchronizacji ruchowego aspektu mowy) (Krasowicz-Kupis, 2008). J. Cieszyńska, zauważa: „[...] prawidłowa analiza i synteza bodźców dźwiękowych jest warunkiem niezakłóconego procesu uczenia się języka w jego mówionej i pisanej formie. Zaburzenia słuchu fonemowego mogą być przyczyną wad wymowy oraz późniejszych problemów z czytaniem i pisaniem" (Cieszyńska, 2001).

Trudności w czytaniu i pisaniu występują bardzo często nawet, gdy dziecko nauczy się prawidłowo artykułować poszczególne głoski. Jak zauważa Skorek: „najczęściej zmienia się wymowa w formie zewnętrznej, natomiast utrwalone wewnętrzne wzorce artykulacyjne pozostają długo niezmienione. Dzieje się tak dlatego, że w mowie wewnętrznej oraz artykulacji utajonej (podczas pisania) wewnętrzny system ruchowo - mowny pozostaje nadal niezmieniony. I chociaż w wyniku ćwiczeń np. słuchu fonematycznego dziecko zaczęło głoskę wymawiać poprawnie, to jednak poprzednie wzorce zostały ukształtowane na niepoprawnej konstrukcji ruchowej i nie podlegaja sankcjonującej kontroli analizatora słuchowego" (Skorek, 2000). Dlatego tak istotne jest, aby dziecko zanim podejmie naukę w szkole miało zakończony rozwój mowy pod względem artykulacyjnym.

\section{Materiał i metody}

Badania dla potrzeb niniejszej publikacji realizowano we wrześniu 2018 wśród 62 uczniów klas I-III wybranych szkół podstawowych powiatu bialskiego, u których stwierdzono zaburzenia artykulacyjne. Ponadto przeprowadzono wywiad z logopedami prowadzącymi terapię tych dzieci. Podstawowym narzędziem wykorzystanym w badaniu była część kwestionariusza obrazkowego, skonstruowanego przez G. Demel. Badano również motorykę i anatomię narządów mowy, analizę dźwiękową wyrazów, powtarzanie wyrazów o trudnej budowie fonetycznej. Dokonano szczegółowej analizy prób pisma (dyktand) uczniów z zaburzeniami artykulacyjnymi.

W grupie badanych było 27 dziewcząt co stanowiło 43,5\% wszystkich badanych i 35 chłopców co stanowiło 56,5\% wszystkich badanych.

\section{Wyniki}

W grupie dzieci mających wady mowy można stwierdzić następujące m.in. nieprawidłowości:

a) nieprawidłowa realizacja głosek sz, ż, cz, dż (deformacje o charakterze interdentalnej artykulacji, substytucje),

b) nieprawidłowa realizacja głosek s, z, c, dz (43 osoby),

c) wadliwa realizacja głoski r (10 osób),

d) mowa bezdźwięczna (6 osób),

e) jąkanie (3 osoby)

Badając sprawność motoryczną narządów artykulacyjnych posłużono się schematem przygotowanym przez J. Kanię. Oceniając sprawność ruchową narządów artykulacyjnych posłużono się 3-stopniową skalą:

1. Sprawność ruchowa narządów mowy w normie (wykonanie wszystkich lub pierwszych 7 układów).

2. Sprawność ruchowa narządów mowy w stopniu średnim (dziecko nie wykonuje kilku układów, 2-3).

3. Sprawność ruchowa narządów mowy zaburzona w stopniu wysokim (dziecko nie wykonuje wszystkich lub większości układów).

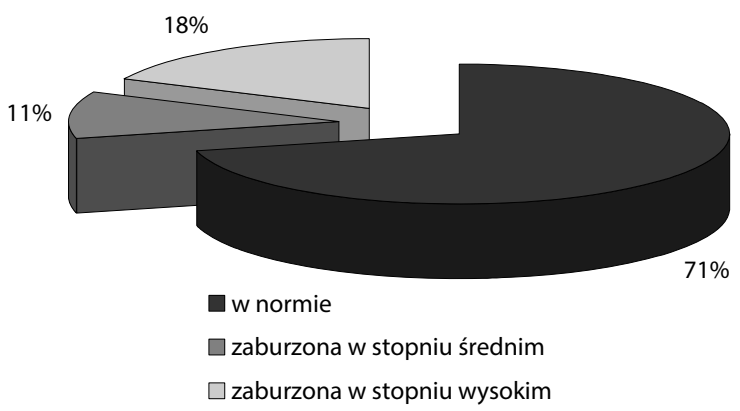

Rycina 1. Wyniki badań sprawności narządów artykulacyjnych

Jak przedstawia powyższy wykres $71 \%$ badanych dzieci miało sprawne narządy artykulacyjne, u $11 \%$ stwierdzono zaburzenia w stopniu średnim, a u $18 \%$ wysokim.

$\mathrm{Na}$ podstawie wywiadu z logopedą można zauważyć niepokojący wzrost liczby dzieci rozpoczynających edukację szkolną, które mają wady wymowy (ponad $40 \%$ ). Pomimo istniejących wielu programów, projektów, które mają na celu wspomaganie rozwoju mowy, można zaobserwować, że przybywa dzieci z zaburzeniami mowy, sześciolat- 
ki mają coraz słabiej rozwiniętą mowę. Analizując wyniki badań, można przypuszczać, iż stan ten nie jest uwarunkowany czynnikami endogennymi (np. sprawność narządów artykulacyjnych badanych dzieci nie zmieniła się znacząco na przestrzeni lat), lecz czynnikami środowiskowymi. Rodzice zbyt mało czasu poświęcają swoim dzieciom, a zatem mniej rozmawiają ze swymi pociechami. Dlatego tak ważne są działania profilaktyczne.
Większość badanych uczniów (52 osoby) z zaburzoną wymową miało trudności w czytaniu i pisaniu.

Uczniowie, którzy nieprawidłowo realizowali głoski dentalizowane (s, z, c, dz, sz, ż, cz, dż) deformując je lub stosując substytucje - podczas dyktanda popełniali szereg błędów.

Poniżej zostały zaprezentowane wybrane prace uczniów (dyktanda) mających zaburzenia artykulacyjne.

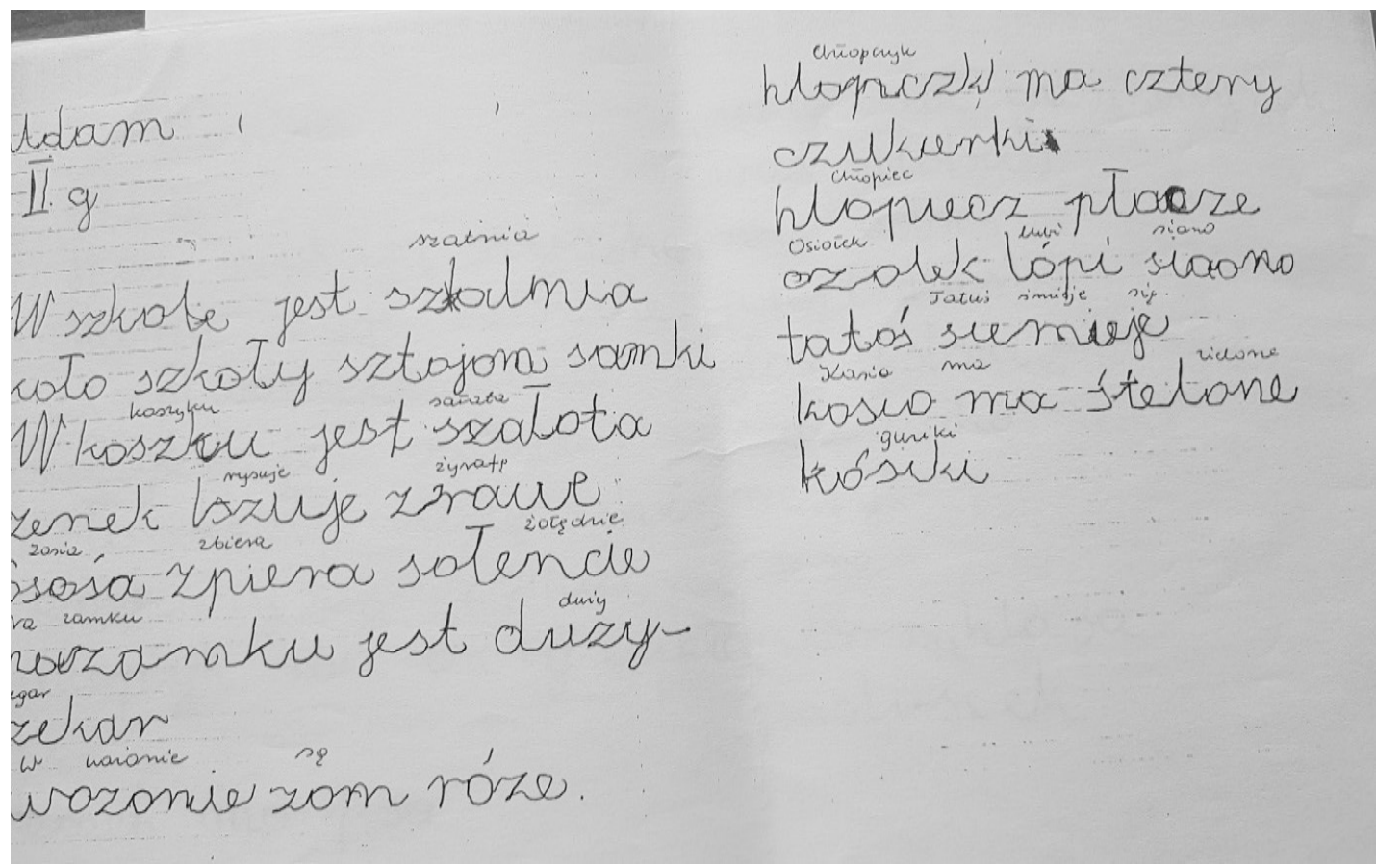

Rycina 2. Dyktando chłopca mającego seplenienie międzyzębowe

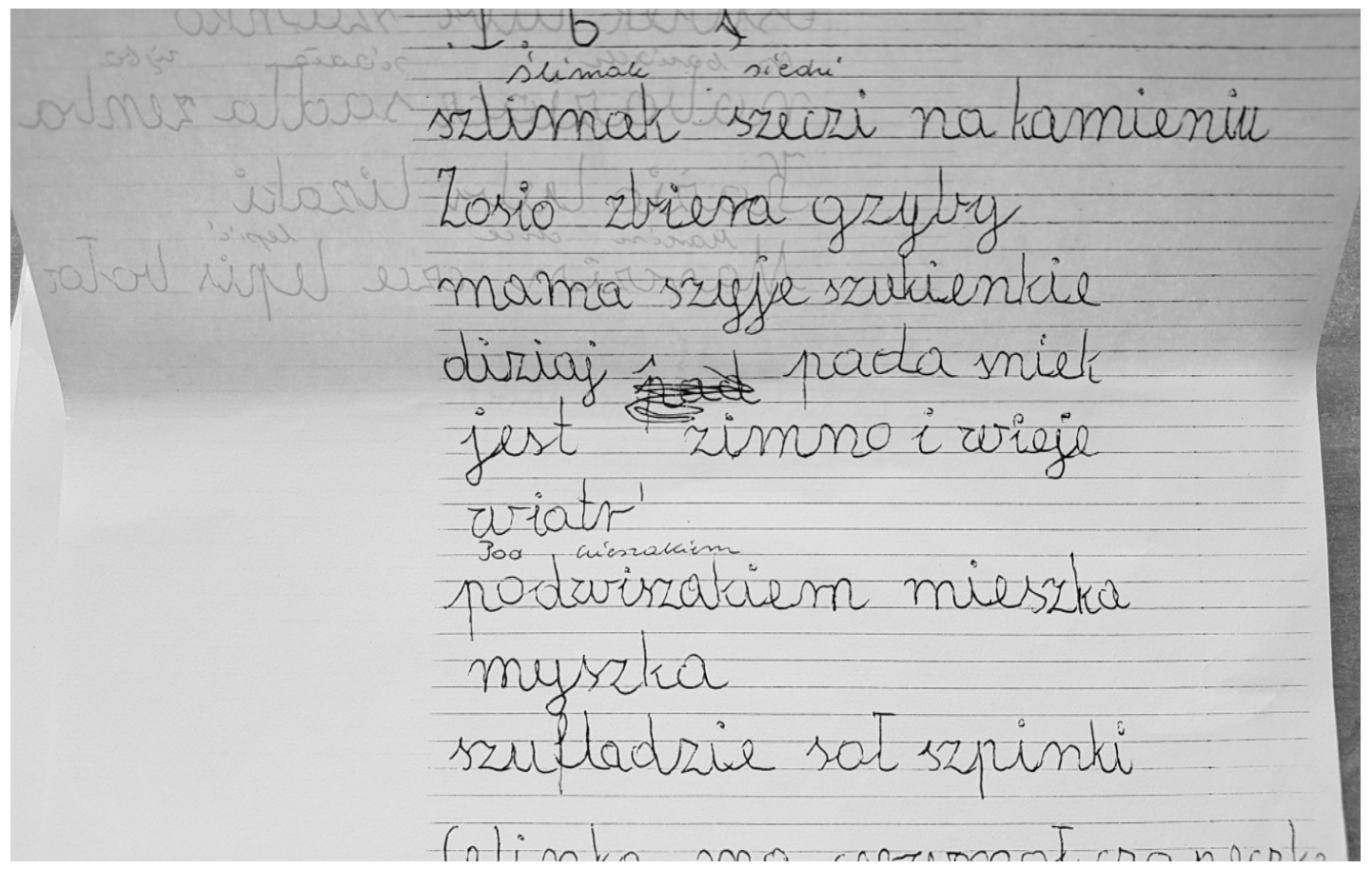

Rycina 3. Dyktando dziewczynki mającej seplenienie (substytucja) 


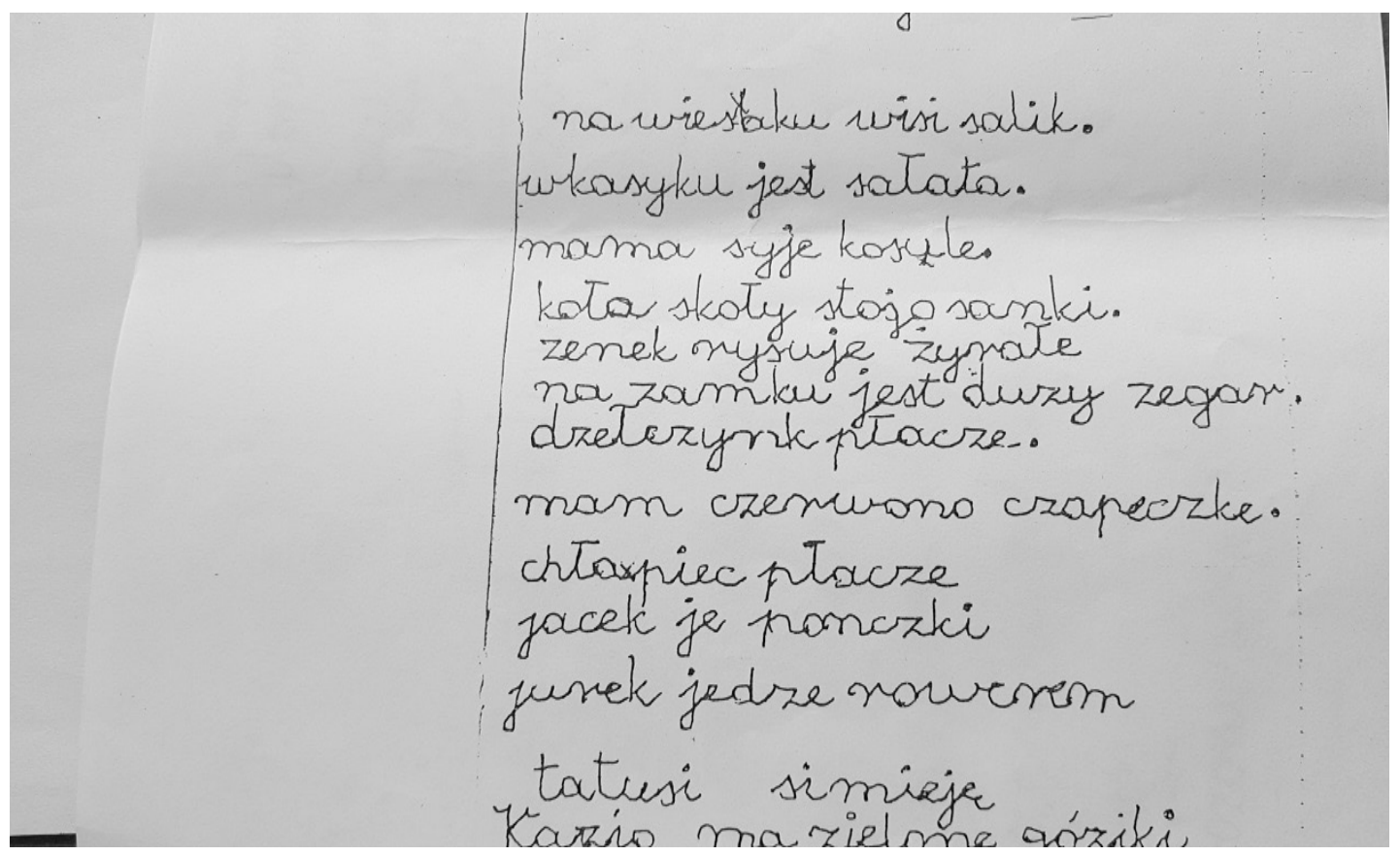

Rycina 4. Dyktando chłopca mającego seplenienie (substytucja)

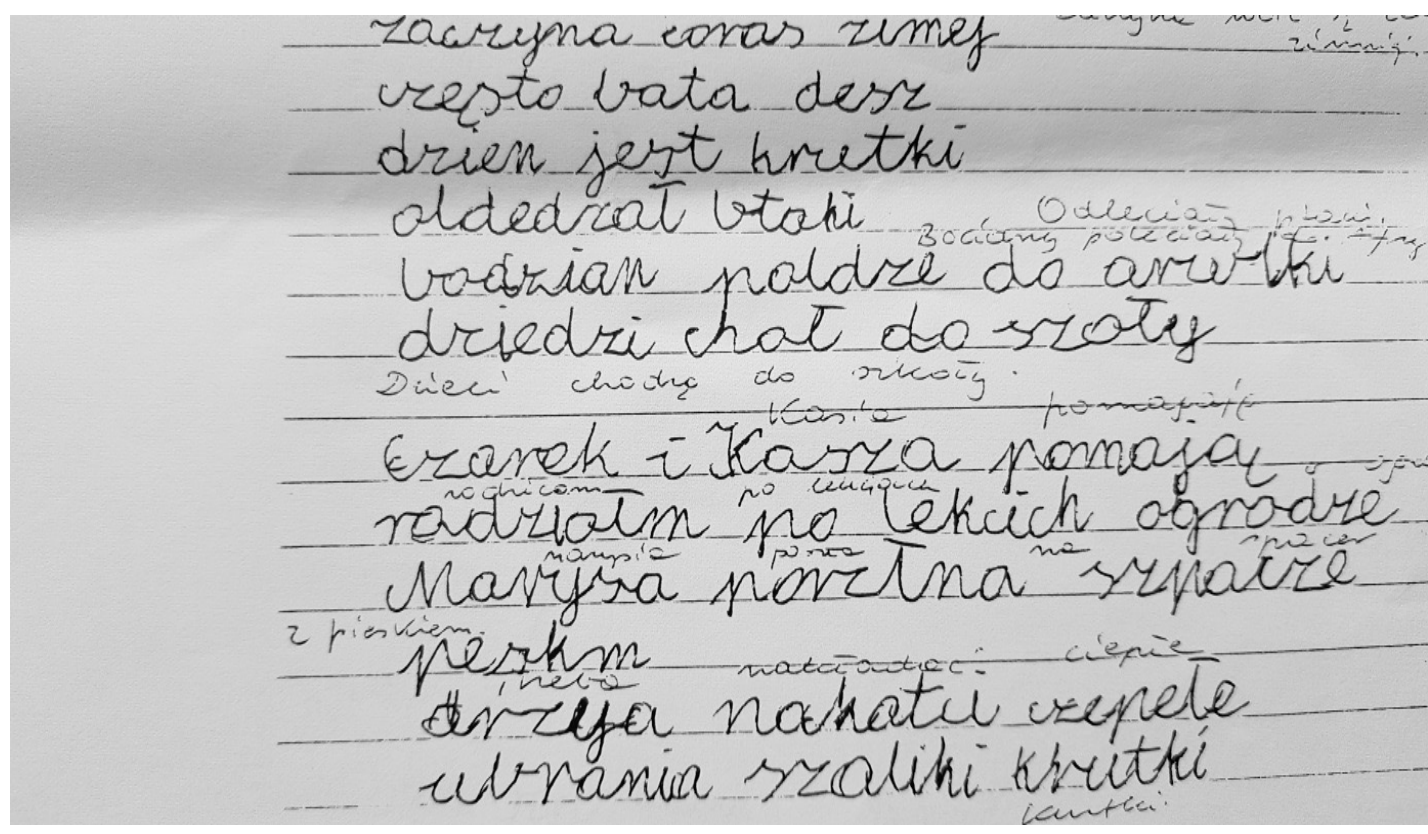

Rycina 5. Dyktando chłopca z dyslalią wieloraką

Wśród dzieci mających wady wymowy, 6 osób miało mowę bezdźwięczną. Wada ta również wpływała na naukę czytania i pisania badanych. 


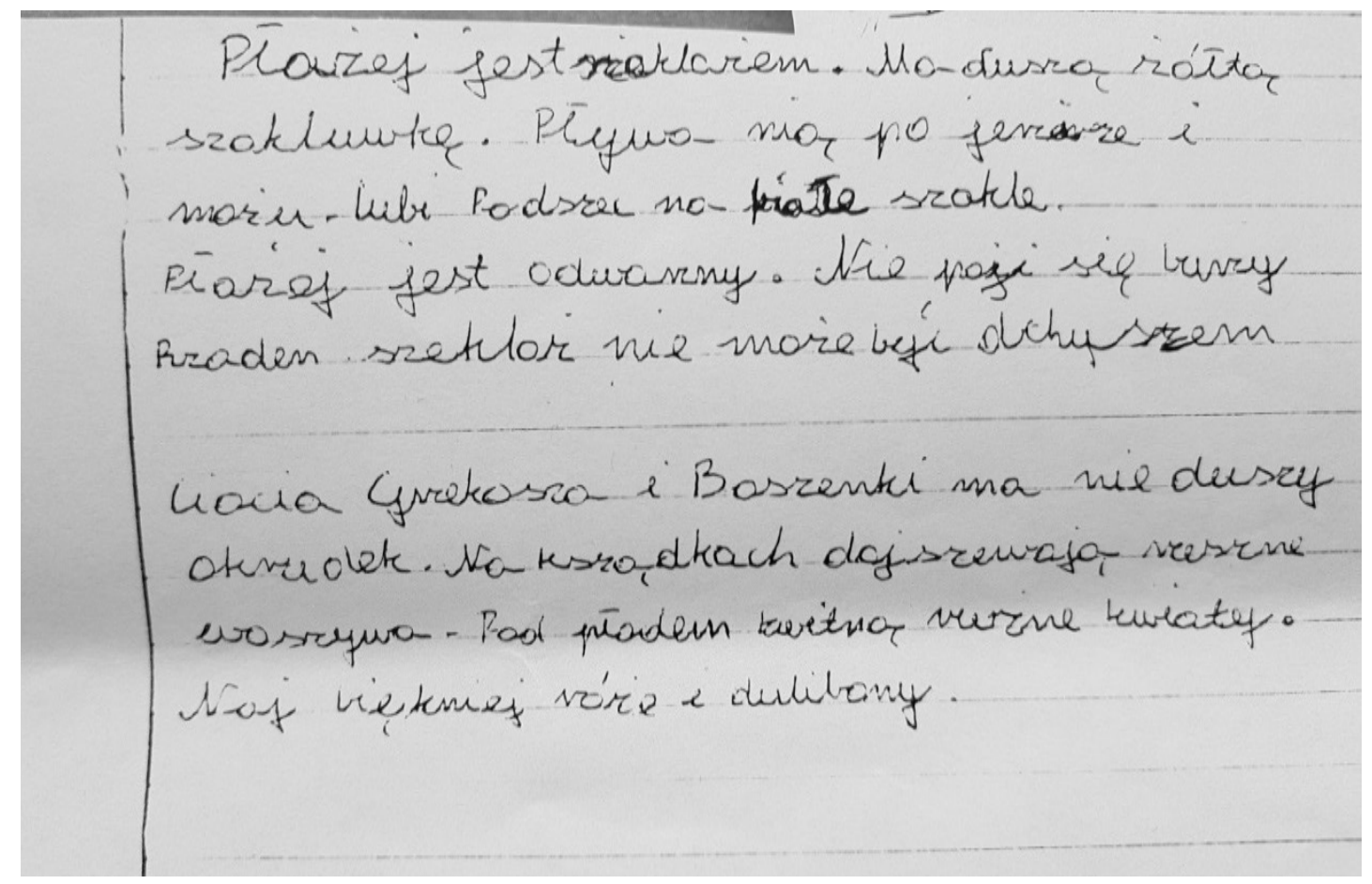

Rycina 6. Dyktando chłopca z mającego mowę bezdźwięczną

\section{Wnioski}

1. Analizując wyniki badań empirycznych można stwierdzić, że liczba dzieci mających wady wymowy w ostatnich latach znacznie wzrosła.

2. Można przypuszczać, iż stan ten jest uwarunkowany przede wszystkim czynnikami środowiskowymi (egzogennymi).
3. Nieumiejętne i niekontrolowane korzystanie z mediów elektronicznych przez dzieci może wpływać na zaburzenia komunikacji werbalnej.

4. Zaburzenia artykulacyjne wpływają na trudności w czytaniu i pisaniu $(83,9 \%$ uczniów $\mathrm{z}$ wadą wymowy miało trudności w czytaniu i pisaniu).

\section{Literatura:}

1. Cieszyńska, J. (2001). Nauka czytania krok po kroku:jak przeciwdziałać dysleksji. Kraków: Wydawnictwo Naukowe Akademii Pedagogicznej.

2. Cieszyńska-Rożek, J. (2013). Metoda krakowska wobec zaburzeń rozwoju dzieci. Z perspektywy fenomenologii, neurobiologii i językoznawstwa. Kraków: Wydawnictwo Omega Stage System.

3. Czelakowska, D.J. (2005). Stymulacja kreatywności językowej dzieci w wieku wczesnoszkolnym. Kraków: Wydawnictwo Naukowe Akademii Pedagogicznej.

4. Dołęga, Z. (2003). Promowanie rozwoju mowy w okresie dzieciństwa - prawidłowości rozwoju, diagnozowanie i profilaktyka. Katowice: Wydawnictwo Uniwersytetu Śląskiego.

5. Dyer, L. (2006). Mowa dziecka. Warszawa: Wydawnictwo K. E. Liber.

6. Ennemoser, M., Schneider, W. (2007). Relations of television viewing and reading: Findings from a 4-year longitudinal study. Journal of Educational Psychology, 99(2), 349-368.

https://doi.org/10.1037/0022-0663.99.2.349

7. Grabias, S. (1994). Logopedyczna klasyfikacja zaburzeń mowy. Audiofonologia, 6, 7-22.

8. Grabias, S. (1996). Typologia zaburzeń mowy. Narastanie refleksji logopedycznej. Logopedia, 23, 87-88.

9. Haliliday, M.A.C. (1975). Learning how to mean: Explorations in the development of language. New York: E. Arnold Ed.

10. Jastrzębowska, G. (2003). Dyslalia. W: T. Gałkowski, G. Jastrzębowska (red.), Logopedia. Pytania i odpowiedzi, t. II (s. 144-149). Opole: Wydawnictwo Uniwersytetu Opolskiego.

11. Jastrzębowska, G. (2003). Opóźnienia rozwoju mowy - przejawy nieprawidłowości rozwojowych. W: T. Gałkowski, G. Jastrzębowska (red.), Logopedia. Pytania i odpowiedzi, t. II (s. 37-68). Opole: Wydawnictwo Uniwersytetu Opolskiego. 
12. Kaczmarek, L. (1988). Nasze dziecko uczy się mowy. Lublin: Wydawnictwo Lubelskie.

13. Kielar-Turska, M. (2003). Rozwój mowy. W: T. Pilch (red.), Encyklopedia pedagogiczna XXI wieku (s. 495509), T. V. Warszawa: Wydawnictwo Akademickie „Źak”.

14. Krasowicz-Kupis, G. (2008). Psychologia dysleksji. Warszawa: Wydawnictwo Naukowe PWN.

15. Rodak, H. (1992). Terapia dziecka z wadq wymowy. Warszawa: Wydawnictwo Polskiej Fundacji Zaburzeń Mowy.

16. Sadowski, B. (2005). Budowa i czynność układu nerwowego z uwzględnieniem mechanizmów sterujących mową. W: T. Gałkowski, E. Szeląg, G. Jastrzębowska (red.), Podstawy neurologopedii (s. 43-97). Opole: Wydawnictwo Uniwersytetu Opolskiego.

17. Sawa, B. (1992). Uwarunkowania i konsekwencje psychologiczne zaburzeń mowy u dzieci. Warszawa: Wydawnictwo Uniwersytetu Warszawskiego.

18. Skorek, E.M. (2000). Dzieci z zaburzeniami mowy wśród rówieśników w klasie szkolnej. Kraków: Oficyna Wydawnicza „Impuls”.

19. Small, G., Vorgan, G. (2011). iMózg. Jak przetrwać technologicznq przemianę współczesnej umysłowości. Poznań: Wydawnictwo Vesper.

20. Spitzer, M. (2013). Cyfrowa demencja. Słupsk: Wydawnictwo Dobra Literatura.

21. Styczek, I. (1979). Logopedia. Warszawa: PWN.

22. Tarkowski, Z. (2003). Jąkanie. Giełkot. W: T. Gałkowski, G. Jastrzębowska (red.), Logopedia. Pytania i odpowiedzi, t. II (s. 176-190). Opole: Wydawnictwo Uniwersytetu Opolskiego.

23. Wołosiuk, B. (2012). Diagnoza i wspomaganie rozwoju mowy dzieci sześcioletnich. W: Z. Palak, D. Chimicz, A. Pawlak (red.), Wielość obszarów we współczesnej pedagogice specjalnej (s. 497-506). Lublin: Wydawnictwo UMCS.

24. Zarębina, M. (1994). Język polski w rozwoju jednostki. Analiza tekstów dzieci do wieku szkolnego. Rozwój semantyczny języka dziecka. Dyskusja nad teoriq Chomskiego. Gdańsk: Glottispol Gdańsk.

25. Zimbardo, P.G. (1999). Psychologia i życie. Warszawa: Wydawnictwo Naukowe PWN.

26. Zimmerman, F.J., Christakis, D.A., Meltzoff, A.N. (2007). Associations between media viewing and language development in children under age 2 years. The Journal of Pediatrics, 151(4), 364-368. https://doi.org/10.1016/j.jpeds.2007.04.071 